\title{
MEDIA LITERACY IN THE STRUCTURE OF PROFESSIONAL COMPETENCE OF FUTURE TEACHERS
}

\section{Halyna Yerko ${ }^{1}$}

DOI: https://doi.org/10.30525/978-9934-26-050-6-44

Today in Ukraine the issue of media literacy is becoming increasingly important, and the need of the population for critical thinking is becoming more pronounced. Media literacy of the young generation is a leading factor in its socialization, learning, becomes a mean of distance and a source of nonformal education. In 2016 the introduction of a new version of the Concept of Media Education in Ukraine, approved by the Presidium of the National Academy of Pedagogical Sciences, is also important for understanding media educational processes in Ukraine.

\footnotetext{
${ }^{1}$ Lutsk Pedagogical Professional College of the Municipal Institution of Higher Education «Lutsk Pedagogical College» of the Volyn Regional Council, Ukraine
} 
German authors Gerhard Tulodzetsky, Bardo Herzig and Silke Grafe [2] in their work «Media education in school and in the classroom» focus on teacher self-development, especially in the field of media literacy. A high level of media literacy and critical thinking, pedagogical skills - these are the competencies that, in their opinion, should have a modern teacher.

Recommendations for the organization of online media literacy training were developed by domestic media experts Tetyana Ivanova and Svitlana Izbash [1]. They emphasize the need for continuous development of media literacy skills for both adults and children. Emphasis is placed not only on the tools for developing media literacy skills, but also on the need to improve them and the ability to explain how to consume information.

Analyzing the latest research and publications connected to the problem, we can say that the introduction of media literacy in educational methodology for civic and historical subjects in the training of primary school teachers, that all led to the choice of research topic.

The purpose of the article is to analyze and clarify the theoretical and didactic features of teaching media literacy in the field of civic and historical education in primary school.

According to recent years researches modern students come to school with significant media experience. Most of them have fairly stable media preferences: favorite movies and TV shows, computer games, magazines, cartoons, online resources, and more.

We have to see the possibility of using media literacy exercises in civic and historical education.

Quite often students turn to the Internet as a source of information, so the exercise «Searching for information on the Internet by keywords» will help them in developing skills working with Internet resources and teach information processing.

The teacher must be able to explain to students the peculiarities of the search engine and the rules of operation. It is worth noting that the search on the Internet does not answer the questions, but only directs users to sources that contain keywords. Thus, their exact choice is important. In order to find the information you need, you need to think about what exactly they want to find and what they will use the found messages for. It is worth emphasizing that you need to consider:

- What amount of information is needed?

- How reliable (true) will the information be?

Students are divided into three groups. Each group receives a card and has to suggest keywords in order to find the answer to the question and suggest their own words that fit in the empty box. Example: 


\section{Card 1}

When was the name of «Ukraine» first mentioned?

\begin{tabular}{|l|l|l|l|l|l|l|}
\hline Ukraine & History & Name & Forthefirsttime & KievanRus & Independence & \\
\hline
\end{tabular}

Card 2

When did the blue and yellow flag become the state symbol of Ukraine?

\begin{tabular}{|l|l|l|l|l|l|l|}
\hline Flag & Ukraine & Yellow & Independence & Officialsymbol & Forthefirsttime & \\
\hline
\end{tabular}

Card 3

When did the trident become the official emblem of Ukraine?

\begin{tabular}{|l|l|l|l|l} 
Trident & Ukraine & Independence & Emblem & Officialcoatofarms \\
\hline
\end{tabular}

The proposed exercise will be effective for use in the integrated course «I explore the world» in primary school.

Today, online resources are widely used to teach media literacy, due to the transition of most educational institutions to online education.

At this form of work the virtual board Padlet will help us. On the board, the teacher can both place teaching materials and create didactic materials.

The Padlet service gives each student the opportunity to post their work, teachers and students to comment on the results of activities. Effective use of the board is the organization of teamwork online.

The Didletic Padlet can be used to configure the class for work and class rules; «Brainstorming»; formation of skills to ask «thin» and «thick» questions; creating a poster and working with it; creation of information retrieval tasks (mentioned above); a story about a prominent historical figure, posting photos, links to resources, video; to place creative works of students; to conduct reflections, etc.

In fact, the same features by the smart application Google Jamboard are provided. It has no restrictions on the size of the free space and the number of participants who can work at the same time, so it will be quite effective for creative activities of the students.

An animated product is another resource that teachers with younger students should work on. Animated films help the process of understanding and memorizing information, affect the emotional state of children. When choosing a cartoon as a mean of learning, it is necessary to pay attention to the following criteria: the problem that is being raised; age of the audience; purpose of creation; style of presenting information; language and images; what ideas after watching it students have.

Exercise «Analyze a cartoon» will promote the formation of critical thinking skills in the analysis of media texts.

Before watching, it is important for the teacher to answer the following questions: which shots, episodes of the film can be identified as key; what impressions are evoked by the images of personalities presented in the cartoon, etc. 
To consolidate the material, it is suggested to view individual fragments of the cartoon, using a still frame, asking questions to students. Example:

1) What information did we get about ... after watching the cartoon?

2) What else does the cartoon tell us?

3) How do you think, is all the information in the cartoon true?

4) How would you check it?

Working with cartoons teaches to perceive and use information; assess the situation; make decisions; make judgments; protect and promote their own interests and values.

Storytelling is another method of forming media literacy of future primary school teachers. Exercises «Photos of my family», «Favorite photo from the family album» will help us with this. The task is to tell a short story about the event in the photo; who is on the picture; what do you remember about that moment? what thoughts or dreams arise when you are viewing photos, etc.

It is important to emphasize that the photo from the family album can be taken only with the permission of the elders, especially if the photo shows some other people, it is advisable to ask them (if possible) if they would not mind using this photo.

Summarizing the exercise, the teacher finds out what mood and impressions of the stories and photos told evoked; emphasizes the importance of following the rules of photo use.

Skills that students gain from exercises: acquire basic skills of «reading information» from photography; understand the importance of photography in preserving knowledge about pedigree; understand how we use the Internet safely to post photos in it; analyze the images on the photos and tell the story according to their plot.

In addition, such classes contribute to the education of the culture of photography, a critical attitude to the plot of the photo as a media content that will be considered by other people or future generations.

Thus, it is necessary to purposefully teach media literacy in classes on teaching methods of civic and historical education, which will contribute to the further development of a person thinking critically, be media competent, one who has a well-established media culture and a stable media mentality.

\section{References:}

1. Ivanova T., Izbash S. (2020). Metodychni «rodzynky» onlajn-treninghu z media ghramotnosti «Budu u trendi: MIH v online!»: praktychnyi posibnyk [Methodical «highlights» of online media literacytraining «Beintrend: MIG inonline!»: A practicalguide]. Kyiv: Akademiia ukrainskoi presy, Tsentr vilnoi presy, $96 \mathrm{p}$.

2. Tulodzietskyi G., Hertsig B., Grafe S. (2020). Mediaosvita v shkoli ta na uroci: Osnovy i pryklady. [Media educationin school and in the classroom: Basicsandexamples]. Kyiv: Akademiia ukrainskoi presy, Tsentr vilnoi presy, 405 p. 